\title{
Recovery of drug residues in equipment and utensils used by compounding pharmacies after standard cleaning procedure
}

\author{
Tassia Prioste, Thiago Ferreira dos Santos Magon, Vinicius Fagundes, Maiara Camotti Montanha, \\ Cristiane Moriwaki ${ }^{1}$, Elza Kimura*
}

Pharmacy Department, Health Sciences Center, State University of Maringá, Maringá, PR, Brazil

\begin{abstract}
Compounding pharmacies have been cited by some athletes as being responsible for compounding capsules contaminated with drugs banned by the International Olympic Committee (IOC). Therefore, the present study was carried out to quantify the amount of residue remaining in the equipment and utensils used for compounding capsules after standard cleaning procedures. For this purpose, captopril (CAP) and acetylsalicylic acid (ASA) were used since these are hard to clean, in addition to hydrochlorothiazide (HTZ) as a banned drug by the IOC. The amounts of residues found in the equipment were: $181.0 \pm 91.8$, $1208 \pm 483.8$ and $431.7 \pm 71.3$ ppm for ASA, CAP and HTZ, respectively. The continuous compounding of these drugs, followed each time by the standard cleaning procedure, showed a linear accumulation of residues for ASA $\left(r^{2}=0.96\right)$ and CAP $\left(r^{2}=0.88\right)$. The residues quantified were greater than the FDA limit for impurities for CAP $(>0.1 \%)$ but not for HTZ. However, the HTZ residue may be detected in the urine of athletes on IOC tests. Therefore, it was concluded that compounding pharmacies should therefore improve their cleaning procedures and test these in order to attain limits below $10 \mathrm{ppm}$, thereby avoiding the contamination of other products.
\end{abstract}

Uniterms: Compounding pharmacy/cleaning procedure/equipments. Pharmacy equipaments/cleaning. Pharmaceutical products/contamination. Captopril. Acetylsalicylic acid. Hydrochlorothiazide.

As farmácias de manipulação têm sido citadas por alguns atletas como sendo responsáveis pela manipulação de cápsulas contaminadas com fármacos proibidos pelo Comitê Olímpico Internacional (COI). Portanto, o presente estudo foi realizado para quantificar o montante de resíduo remanescente nos equipamentos e utensílios usados para manipular cápsulas após o procedimento padrão de limpeza. Para este propósito, o captopril (CAP) e o ácido acetilsalicílico (ASA) foram usados por serem fármacos de difícil remoção e a hidroclorotiazida (HTZ), por ser um fármaco proibido pelo COI. As quantidades de resíduos encontradas nos equipamentos após a limpeza foram 181,0 \pm 91,8, $1208 \pm 483,8$ e 431,7 \pm 71,3 ppm para ASA, CAP e HTZ, respectivamente. A manipulação contínua dos fármacos seguida pelo procedimento de limpeza mostrou acúmulo de resíduo linear para $\operatorname{ASA}\left(\mathrm{r}^{2}=0,96\right)$ e CAP $\left(\mathrm{r}^{2}=0,88\right)$. A quantidade de resíduo de CAP foi maior que o limite de impureza sugerido pelo $\operatorname{FDA}(>0,1 \%)$, mas não para HTZ, mas mesmo assim, o resíduo de HTZ pode ser detectado na urina dos atletas submetidos aos testes do COI. Em conclusão, as farmácias de manipulação deveriam, portanto, melhorar o procedimentos de limpeza e testá-los para que alcancem limites abaixo de 10 ppm para evitar contaminação nos outros produtos.

Unitermos: Farmácia de manipulação/procedimentos de limpeza/equipamentos. Equipamentos farmacêuticos/limpeza. Produtos farmacêuticos/contaminação. Captopril. Ácido acetilsalicílico. Hidroclorotiazida.

Correspondence: Elza Kimura. Departamento de Farmácia. Universidade Estadual de Maringá. Av. Colombo, 5790 Bloco K-68 - 87020-900 - Maringá - PR, Brasil. E-mail: ekimura@uem.br 


\section{INTRODUCTION}

The Football World Cup in 2014 and the Olympic Games in 2016 will be hosted by Brazil, and in the quest to be the strongest and fastest, many athletes consume different nutritional and energetic supplements and, in some cases, performance-enhancing drugs forbidden by the International Olympic Committee (IOC) (Müller, 2010).

Traces of diuretics are commonly found in the urine samples of athletes, such as in the case of a swimming gold medalist who alleged he had ingested nutritional supplements contaminated with prohibited substances compounded by a local pharmacy (ESPN, 2011), and of a paralympic athlete who consumed green tea capsules contaminated with a banned diuretic (IPC, 2012). Based on these claims, they received a light penalty and a 9-month suspension for anti-doping rule violation, respectively, and the reliability of all compounding pharmacies was called into question.

The handling of different medicines is inherent in the pharmaceutical profession and plays an important role in the care of individual patients; however, debates often arises over errors and adverse events caused by inappropriately compounded formulations, resulting in risk to the patient and possible legal action (Gudeman et al., 2013).

The USP 34 chapter 795 (USP, 2011) and the Good Compounding Practices for Pharmacies edited by the Brazilian Health Surveillance Agency (ANVISA, 2006) recommend that equipment and utensils be cleaned and formulations compounded in a clean environment, but no confirmation of recovery of residues is required after cleaning procedures, as is required for drug manufacturing laboratories (FDA, 1993).

To date, no reports demonstrating the amount of residues remaining on utensils and equipment used by compounding pharmacies have been published. Therefore, the objective of this study was to quantity the residues recovered from pestle-and-mortar and encapsulation devices used for mixing powders and filling capsules after standard cleaning procedures used by the majority of compounding pharmacies in Brazil. Based on the criterion of being hard to clean, captopril (CAP) and acetylsalicylic acid (ASA) were chosen because they strongly adhere to surfaces and are unstable in water, along with hydrochlorothiazide (HTZ) because it is banned by the IOC.

\section{MATERIAL AND METHODS}

\section{Spectrophotometric UV-Vis validation methods}

\section{Standard Solution Preparation}

Stock solutions of CAP, ASA and HTX were prepared to a final concentration of $100 \mathrm{mg} / \mathrm{L}$ by dissolving $25 \mathrm{mg}$ of active substances (USP Reference Standard) in $0.1 \mathrm{~N}$ hydrochloride acid solution, $2 \mathrm{~mL}$ of ethanol and further dilution with $0.05 \mathrm{M} \mathrm{pH} 4.5$ acetate buffer or $0.1 \mathrm{M}$ sodium hydroxide solutions, respectively, in $250 \mathrm{~mL}$ volumetric flasks and used immediately. The calibration curves were built at concentrations of 10, 15, 20, 30, 50 and $70 \mathrm{mg} / \mathrm{L}$ for ASA and 1, 5, 10, 15 and $20 \mathrm{mg} / \mathrm{L}$ for both CAP and HTZ. The absorbances were measured at wavelengths of 212, 265 and $275 \mathrm{~nm}$ for CAP, ASA, and HTZ, respectively, using a model UVmini-1240 UV-Vis-spectrophotometer (Shimadzu, Japan).

\section{Validation}

The validation procedure was carried out according to the Guidance for Industry - the Analytical Method Validation recommended by the U.S. Food and Drug Administration (FDA, 2000).

\section{Pharmaceuticals and compounding products}
- $\quad$ ASA: capsules containing $100 \mathrm{mg}$ ASA and $100 \mathrm{mg}$ of starch
CAP: capsules containing $25 \mathrm{mg}$ CAP and $100 \mathrm{mg}$ of lactose
- $\quad$ HTZ: capsules containing $25 \mathrm{mg} \mathrm{HTZ}$ and $100 \mathrm{mg}$ of lactose

The active compounds were weighed and mixed with the amount of excipient required to fill 60 capsules. Each compound was mixed with lactose (CAP and HTZ) or starch (ASA) in a mortar (outer diameter $10 \mathrm{~cm}$, depth $5 \mathrm{~cm}$ ) by rotating a pestle clockwise 10 times and anti-clockwise 10 times. After mixing the active compounds with the excipients, each powder mix was spread onto the tray of the encapsulation device and the capsules were filled. This compounding sequence was carried out in triplicate.

\section{Cleaning procedure and drug recovery}

The cleaning procedure followed the standard operating procedure (SOP) used by 3 different compounding pharmacies in Maringá city, Paraná State, Brazil was followed in the study. Briefly, the manual encapsulation devices (Capsutec, Brazil) were disassembled after routine compounding and the trays cleaned with dry paper wipes and then with paper wipes moistened with $70 \%$ alcohol, and dried with a hair dryer. The same cleaning procedure was followed for the mortar and pestles. At the end of each day, the encapsulation 
devices were disassembled and all component parts were immersed in water for 15 minutes, washed with detergent and a brush, rinsed with tap water followed by distilled water then immersed in $70 \%$ alcohol solution for 15 minutes and allowed to dry in a $40{ }^{\circ} \mathrm{C}$ chamber.

The recovery procedure of the residues from the encapsulation devices was carried out after standard cleaning with dry paper wipes. The disassembled devices were rinsed into a tray containing $500 \mathrm{~mL}$ of the same solvents used to quantify each of the active compound described in the validation method, in order to minimize solvent interferences or stability problems during the analysis, maximize drug solubility and improve recovery. The trays were stirred for 10 minutes at $50 \mathrm{rpm}$ and the solvents were collected, filtered and the residues analyzed by the UV-Vis spectrophotometer method. To determine the accumulation of residues after repeated compounding procedures of the same compound, the same procedure (compounding, cleaning, drying, rinsing, filtering and UV-Vis analysis) was carried out after 1, 3, 5 and 7 compounding procedures and a linear regression method was applied using Microsoft Excel 2010 ${ }^{\circledR}$ to ascertain whether the residues increased proportionally to the number of compounding procedures.

For the drug recovery procedure from mortar-andpestle residues, $50 \mathrm{~mL}$ of the solvents used to quantify the active substances in the validation method were used and slow rotations performed to remove the residues. The solvents were then filtered and analyzed by the UV-Vis spectrophotometer method.

The concentrations of the recovered residues were calculated from the absorbance measured for each sample and plotted on their respective calibration curve to determine the final concentration of the residues. In order to determine the total residue amount remaining in the encapsulation device after standard cleaning, the calculated concentration of each sample was multiplied by 500 (dilution factor $=500 \mathrm{~mL}$ ) and then transformed into ppm (parts per million, namely, the proportion of each microgram of residue recovered after compounding and cleaning for each gram of active substance, e.g. CAP or $\mathrm{HTZ}=25 \mathrm{mg}$ active substance $\mathrm{x} 60$ capsules $=1.5 \mathrm{~g}$ ). The dilution factor for pestle and mortar was 50 .

The compounding procedures, followed by cleaning and recovery procedures, were carried out three times for each active substance and the mean and standard deviation calculated using Microsoft Excel ${ }^{\circledR}$.

\section{RESULTS AND DISCUSSION}

This study shows that after performing standard cleaning of compounding equipment, large quantities of residues were recovered for all of the drugs tested, and that these residues can contaminate the next product compounded using the same equipment.

The analytical method of UV-Vis spectrophotometry was chosen because most compounding pharmacies cannot afford high-performance liquid-chromatography equipment but have a spectrophotometer in their laboratories.

The spectrophotometric validation of the active ingredients used in this study followed the methods described by the USP 34 - dissolution test (Table I) and all procedures met the requirements of the analyticalvalidation methods. The linearity concentrations were based on the lower limit for contamination accepted by the FDA of below $10 \mathrm{ppm}$.

TABLE I - Validation parameters of spectrophotometric methods for the drugs

\begin{tabular}{lccc}
\hline Parameters & ASA & CAP & HTZ \\
\hline Linearity (mg/L) & $8-30$ & $1-20$ & $1-20$ \\
$\mathrm{R}^{2}$ & 0.9992 & 0.9991 & 0.9998 \\
Accuracy (\%) & $96.8 \pm 3.3$ & $100.7 \pm 0.2$ & $99.6 \pm 3.7$ \\
Precision (\%) & 3.97 & 0.72 & 2.65 \\
LOQ (mg/L) & 0.91 & 0.33 & 0.03 \\
LDQ (mg/L) & 3.03 & 0.10 & 1.02 \\
\hline
\end{tabular}

LOQ and LDQ denote Limit of Quantification and Limit of Detection, respectively.

High quantities of residues were found for all drugs on the encapsulation devices and pestle and mortar after the standard cleaning procedure had been carried out by trained technicians. The average amount recovered from the encapsulation device and mortar and pestle after one compounding procedure for ASA, CAP and HTZ are shown in Table II.

TABLE II - Residues recovered after one compounding procedure followed by standard cleaning procedure

\begin{tabular}{lcc}
\hline Drugs & $\begin{array}{c}\text { Encapsulation } \\
\text { Device } \\
\text { Mean } \pm \text { SD }\end{array}$ & $\begin{array}{c}\text { Pestle \& Mortar } \\
\text { Mean } \pm \text { SD }\end{array}$ \\
\hline ASA $(\mathrm{ppm})$ & $181.0 \pm 91.8$ & $33.8 \pm 3.5$ \\
CAP $(\mathrm{ppm})$ & $1208.0 \pm 483.8$ & $385.3 \pm 47.3$ \\
HTZ $(\mathrm{ppm})$ & $431.7 \pm 71.3$ & $363.0 \pm 77.6$ \\
\hline
\end{tabular}

The ppm values represent $1 \mathrm{mg}$ of residue remaining after compounding $1 \mathrm{~g}$ of active compound, and are expressed as Mean and Standard Deviation (SD) after triplicate assays. 
The residues in the next product were not measured because of limitations of the analytical method used, but alternatively, the residues accumulated after several compounding and cleaning procedures of the same active ingredient were quantified. Also, to avoid contaminant residues from previous compounding procedures, the encapsulation devices were washed, dried and tested by checking whether any residue could be quantified.

A linear correlation given by the coefficient $r^{2}$ was found between the number of compounding procedures and the amount of accumulated residue for CAP $\left(r^{2}=0.8837\right)$ and ASA $\left(r^{2}=0.9596\right)$, but not for HTZ $\left(r^{2}=0.0538\right)$, on the encapsulation devices (Figure 1).

The amounts of residues recovered after cleaning the devices were very high and have the potential to contaminate other products.

This is the first time the amount of residue remaining after standard cleaning procedures of compounding devices used by compounding pharmacies has been quantified. With regard to toxicity, the quantities of residues found in this study show that these drugs are not likely to be toxic to patients of subsequently compounded products. However, for athletes, these quantities of residues are sufficient to contaminate subsequent products and be detected in the urine or plasma of the athletes given the highly sensitive analytical methods used by the IOC, such as mass spectrometry and immunochemical methods, whose sensitivity limits are measured in picograms and femtograms (Deventer et al., 2009).

Each compounding pharmacy adopts their own cleaning procedure and verification of the cleaning procedure is usually carried out by visual examination; that is, checking that no residue particles are visible. However, this does not guarantee that equipment is free of residues. FDA guidelines recommend a maximum drug contaminant limit of $0.1 \%$ or $1000 \mathrm{ppm}$ for cleaning validation procedures, but do not consider drug contaminants in the same way as impurities such as heavy metals, chlorides, sulfates and arsenic, whose maximum levels must be below 10 ppm in raw materials. Nevertheless, some pharmaceutical manufacturers have established contaminant levels for their cleaning validation approval of below $10 \mathrm{ppm}$ in subsequent products, or $1 / 1000$ of the minimum daily dose of the active compound in relation to the maximum daily dose of the subsequent product (LeBlanc, 2002).

If the residue limits of $0.1 \%$ or $1000 \mathrm{ppm}$ are followed, the cleaning procedures used by the compounding pharmacies would meet FDA requirement for ASA and HTZ, but not for CAP. Adoption of $10 \mathrm{ppm}$ as a limit would
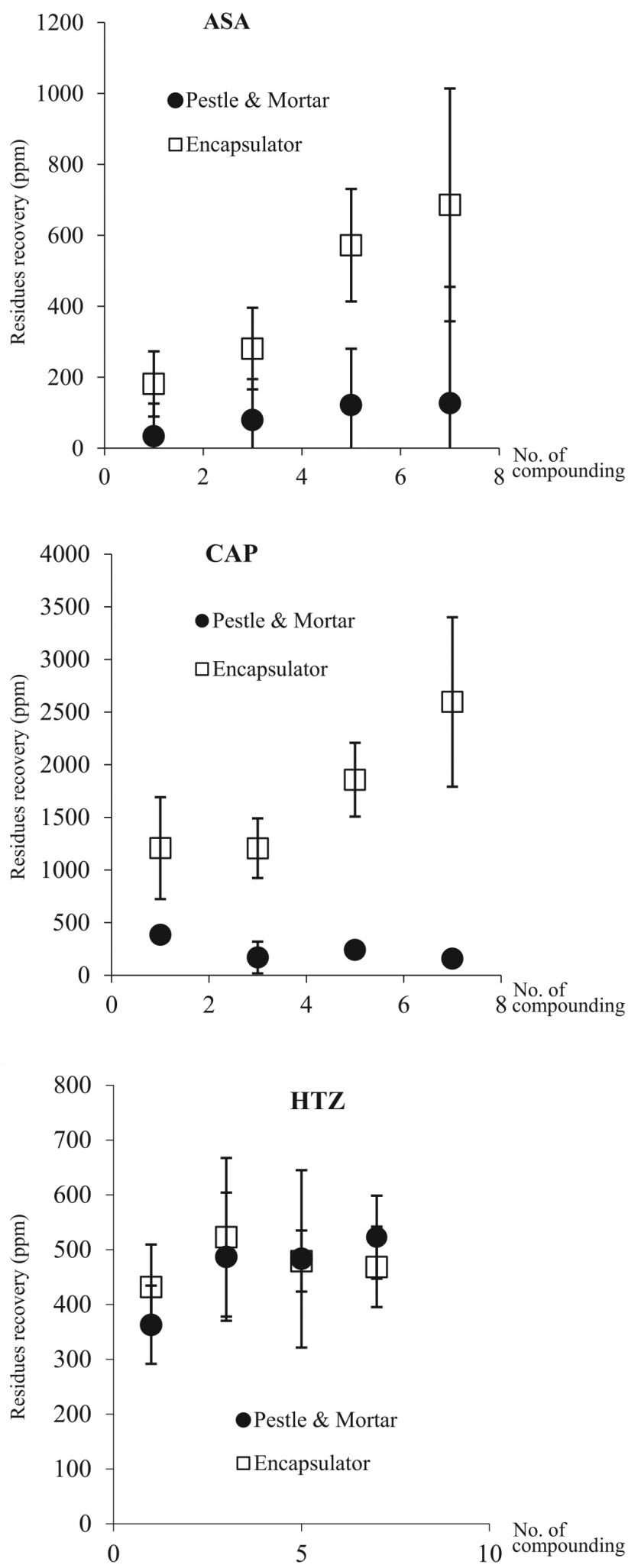

FIGURE 1 - Residues of acetylsalicylic acid, captopril and hydrochlorothiazide after consecutive compounding and cleaning procedures. *ppm values represent 1 microgram of residue remaining after compounding $1 \mathrm{~g}$ of active compound, and are expressed as the mean and SD after triplicate assays. 
be more appropriate, as the drug levels in blood or urine after intake of capsules contaminated with $<10$ ppm of residue would be close to the quantification and detection limits, even when using the most sensitive detection methods such as chromatography mass spectrometry (Thevis, Thomas, Schanzer, 2013). Furthermore, the most important outcome for the compounding pharmacies is that they would not be responsible for contaminating products with banned drugs.

Washing the equipment is time-consuming as it takes a long time to dry all the component parts. However, because of the high volume of preparations being compounded using different ingredients, these devices must be available quickly and having one encapsulation device for every formulation is not economically viable.

Cleaning validation procedures should, therefore, also be recommended for non-sterile products from compounding pharmacies, with "the hardest to clean" criteria being adopted, encompassing hydrophobic or unstable drugs or those that strongly adhere to surfaces.

In order to achieve a high level of quality in compounding pharmacy preparations, the standard cleaning procedure of equipment should be improved and reviewed in order to remove the vast majority of residues adhered to surfaces and cavities of encapsulation devices.

\section{CONCLUSIONS}

The quantity of residues recovered from the encapsulation devices after the standard cleaning procedures used by the compounding pharmacies in our study, may be sufficiently high to contaminate the next compounded product, where these contaminants may subsequently be detected in urine samples using highly sensitive methods. Cleaning procedures should, therefore, be improved in order to keep residue amounts below the 10 ppm limit.

\section{ACKNOWLEDGEMENTS}

The authors would like to thank the Fundação Araucária and the Science and Technology Secretariat of Paraná State, Brazil, for financial support. We would also like to thank pharmacist Eliane Tabuti for technical assistance and Peter J. Grimshaw for translating the manuscript to English.

\section{REFERENCES}

ANVISA. Agência Nacional de Vigilância Sanitária. Guias da Qualidade. Available at: < http://www.anvisa.gov.br/ inspecao/guias_qualidade>. Acessed on: 14 Jan 2014.

DEVENTER, K.; POZO, O.J.; VAN EENOO, P.; DELBEKE, F.T. Detection of urinary markers for thiazide diuretics after oral administration of hydrochlorothiazide and altiziderelevance to doping control analysis. J. Chromatogr, v.1216, n.12, p.2466-2473, 2009.

ESPN. Entertainment and Sports Programming Network. Cesar Cielo's pharmacy blamed. Available at: $<$ http:// espn.go.com/olympics/swimming/story/_/id/6815407/ pharmacy-blamed-world-champion-swimmer-cesar-cielopositive-doping-test $>$. Accessed on: 14 Jan 2014.

FDA. U.S. Food and Drug Administration. Validation of Cleaning Processes (7/93). Available at: $<\mathrm{http}: / / \mathrm{www}$.fda. gov/ICECI/Inspections/InspectionGuides/ ucm074922. htm>. Acessed on: 14 Jan 2014.

FDA. U.S. Food and Drug Administration. Guidance for Industry Analytical Procedures and Methods Validation. Available at: http://www.fda.gov/downloads/Drugs/ Guidances/ ucm122858.pdf. Accessed on: 14 Jan 2014.

GUDEMAN, J.; JOZWIAKOWSKI, M.; CHOLLET, J.; RANDELL, M. Potential risks of pharmacy compounding. Drugs, v.13, p.1-8, 2013.

IPC. INTERNATIONAL PARAOLYMPIC COMMITTEE. Brazilian Athlete Sanctioned after Anti-Doping Rule Violation. Available at: http://www.paralympic.org/pressrelease/brazilian-athlete-sanctioned-after-anti-doping-ruleviolation. Accessed on: 14 Jan 2014.

LEBLANC, D.A. 'Visually clean' as a sole acceptance criterion for cleaning validation protocols. PDA J. Pharm. Sci. Tech., v.56, p.31-36, 2002.

MÜLLER, R.K. History of doping and doping control. In: THIEME, D.; HEMMERSBACK, P. (Eds.) Doping in sports. Handbook of experimental pharmacology, n.195. Berlin Heidelberg: Springer-Verlag, 2010. p.01-23. 
THEVIS, M.; THOMAS, A.; SCHANZER, W. Targeting prohibited substances in doping control blood samples by means of chromatographic-mass spectrometric methods. Anal. Bioanal. Chem v.405, p.9655-9667, 2013.
UNITED STATES PHARMACOPOEIA. USP. The United States Pharmacopeial Convention 34.ed, 2011. Available at: http://www.usp.org/sites/default/files/usp_pdf/EN/gc795. pdf. Acessed on: 14 Jan 2014.

Received for publication on $06^{\text {th }}$ February 2014 Accepted for publication on $18^{\text {th }}$ June 2014 